\title{
Sorting Research of Ocean Engineering Enterprise Informatization Projects based on Risk Assessment
}

\author{
Yan Song and Shuang Yao \\ School of Economics and Management, Harbin Engineering University \\ songyan@hrbeu.edu.cn,alloniam@163.com
}

\begin{abstract}
Due to limited time and resources, ocean enterprise usually give priority to low level of risk project to realize informatization. According to informatization projects content of ocean engineering project, constructing an index system of ocean engineering informatization project based on risk assessment of personnel, capital, organization and technology in total of four perspectives. Utilizing the advantage of Fuzzy TOPSIS of multiple attribute decision-making and limited amount of information decision advantage. The propose of the study is to develop a sorting model of ocean engineering informatization project based on risk level, then sorts the risk of four candidates ocean engineering informatization project, and proceeding the empirical analysis. By observing the result, Al has the minimum risk level of informatization, which is ocean enterprise informatization preferred.
\end{abstract}

Keywords: Risk of informatization; Sorting; Fuzzy-TOPSIS; sensitivity analysis

\section{Introduction}

Due to the step of ocean resources development pace accelerates, high oil prices continue to soar accelerating the process to explore oil from ocean, 53\% of Chinese new oil production is coming from the ocean, offshore oil and gas exploration and development has become the main rise in crude oil production in our country, as the core competitiveness of enterprises, ocean engineering enterprise informatization projects aiming at increasing business efficiency and protecting corporation strategy, more severe, nonsupportting self-developed in domestic for a long term, abroad informatization software needed secondary development, it is not only costly but also appearing "acclimatized" phenomenon. With Ocean engineering enterprises accelerating the pace of informatization, ocean engineering devote more to infomatization projects which has low risk level [1].

At present, informatization project of ocean engineering mainly focused on risk identification, precontrol and decision-making related research. Wenhua Ma [2] explored the new management mode of marine electrical apparatus in view of risk identification and precontrol. Dong Jiang Guo [3] based on entropy coefficient method proposed combining enterprise information technology with subjective judgment of information of decision-makers .Jianxun Huang, Wei Ren [4] integrate the probability level, risk impact level and risk level to build a special shipbuilding risk assessment matrix. K.T.Yeo[5] according to the rate of information system project failure remains high in comparison with other high-tech projects, create a systemic framework that is broad enough to represent a wide range of possible factors that may impact performance of informatization project, and use the framework to delineate and assess the impact of different classes of influencing factors, then proposed that the organizational contexts and a formalized technology play an positive influence to informatization project. DeLone and McLean [6] undertook a review of the research published during the period 1981- 
1987. They identified six variables or dimensions of IS success: System Quality, Information Quality, Use, User Satisfaction, Individual Impact, and Organizational Impact.

Analysis found that in view of the ocean engineering informatization project (hereinafter referred to as the "informatization project") only from the single perspective (such as electrical equipment) for local project risk analysis, or the comprehensive impact based on some of above factors, another research perspectives is evaluating the project process. However, based on risk perspectives with a complete informatization projects index system to construct a risk sorting of informatizatin projects is scarcely. This article attempts to thoroughly analysis informatization projects risk overall marine engineering enterprises. In the condition of lack of project information, gathering over a few representatives marine engineering expertises, combined with field research and literature research, developed a risk evaluation model of marine engineering enterprise informatization project based on Fuzzy-TOPSIS, then achieve an effective sort of informatization technology projects based on risk level, and finally analyze the effect of evaluation through small changes of risk index weights by sensitivity analysis (SA).

\section{Based introduction of Fuzzy-TOPSIS}

TOPSIS method was first proposed by Hwang and Yoon in 1987, which is commonly used in systems engineering for limited multi-objective decision analysis techniques, meanwhile is a wide application of multi-attribute AHP comprehensive evaluation. Comparing with the traditional multivariate statistical analysis, it has advantage of simple calculation, limited sample information, little impact of subjective factors [3] .The paper attempt to construct group sorting models of incomplete information[7,8]. In fuzzy set theory, the linguistic terms (session text) can be transferred into fuzzy number. Table 1 shows the match for projects of linguistic terms value and Triangular fuzzy membership.

Fuzzy-TOPSIS method is introduced in linguistic scale and to calculate projects' distance from fuzzy positive ideal solution (FPIS) and fuzzy negative ideal solution (, FNIS), then based on correlation coefficient close distance $\mathrm{CCi}$, by comparing the correlation distance then compute closeness coefficient $(\mathrm{CCi})$ of candidate projects to evaluate the pros and cons of alternatives. Figure 1 presents a graphical illustration of FPIS and FNIS respectively. Two alternatives A1 and A2 are being evaluated with respect to their distances from FPIS and FNIS respectively. If the goal is to maximize the selected criteria, then choose solutions which are closest FPIS and farthest from FNIS; on the contrary, if the goal is to minimize the index, then select the nearest FNIS and farthest away from FPIS.

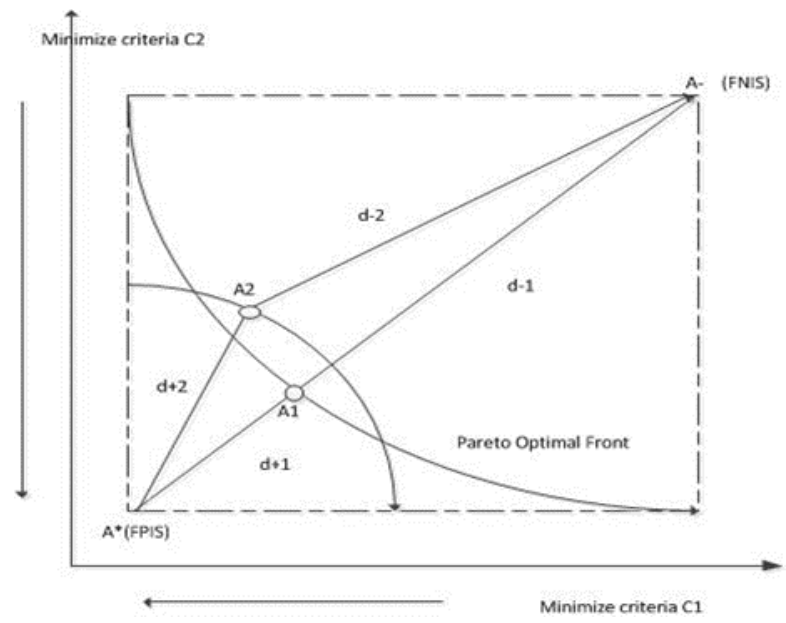

Figure 1. Implication of FPIS and FNIS 
Fuzzy-TOPSIS is presented as follows:

Step1 index evaluation mission:

Let us assume that there are $\mathrm{m}$ possible candidates called $A=\left\{A_{1}, A_{2}, \ldots, A_{m}\right\}$ to evaluated against $\mathrm{n}$ indicators, $C=\left\{C_{1}, \mathrm{C}_{2}, \ldots, \mathrm{C}_{n}\right\}$.The weights are denoted by $\omega_{j}(\mathrm{j}=1,2, \ldots, \mathrm{n})$.In our study, we are using AHP to obtain criteria ratings. For every candidate project, professors assess through scoring. In the same time, index $C_{j}(\mathrm{j}=1,2, \ldots, \mathrm{n})$ scorings. $\tilde{R}_{k}=\tilde{x}_{i j k}(\mathrm{i}=1,2, \ldots, \mathrm{m} ; \mathrm{j}=1,2, \ldots, \mathrm{n} ; \mathrm{k}=1,2, \ldots, K)$ and membership function is expressed as $\mu_{\tilde{R}_{k}}(\mathrm{x})$ 。

Triangular fuzzy number can be defined by a triplet $\tilde{a}=\left(\mathrm{a}_{1}, \mathrm{a}_{2}, \mathrm{a}_{3}\right)$, triangular fuzzy number is widely used in practice $[11,12]$, the membership functions of triangular fuzzy number $\tilde{a}$ is defined by:

$$
\mu_{\tilde{a}}(\mathrm{x})=\left\{\begin{array}{cc}
0, & x<a_{1} \\
\frac{x-a_{1}}{a_{2}-a_{1}} & a_{1} \leq x \leq a_{2} \\
\frac{a_{3}-x}{a_{3}-a_{2}} & a_{2} \leq x \leq a_{3} \\
0 & x>a_{3}
\end{array}\right.
$$

Where ${ }^{a_{1}, a_{2}, a_{3}}$ are all real numbers and $a_{1}<a_{2}<a_{3}$, when the fuzzy number is ${ }_{2}, x$ obtains the maximal grade, that is $\mu_{\tilde{a}}(\mathrm{x})=1$; when the value of $\mathrm{x}$ is ${ }^{\mathrm{a}_{1}}$, $\mathrm{x}$ obtains the minimal grade ,that is $\mu_{\tilde{a}}(\mathrm{x})=0$; And the narrower the interval [ ${ }_{1}, \mathrm{a}_{3}$ ], the lower is the fuzziness of the evaluation data.

Table 1. The Linguistic Scale Transformation to Fuzzy Membership Function

\begin{tabular}{lc}
\hline linguistic scale & membership function \\
\hline Very poor(VP) & $(1,1,3)$ \\
Poor(P) & $(1,3,5)$ \\
Fair(F) & $(3,5,7)$ \\
Good(G) & $(5,7,9)$ \\
Very Good(VG) & $(7,9,9)$ \\
\hline
\end{tabular}

Step 2 Compute aggregate fuzzy comprehensive ratings for criteria and candidate project:

Fuzzy ratings from experts are described as triangular fuzzy number. $\tilde{R}_{K}=\left(\mathrm{a}_{k}, \mathrm{~b}_{k}, \mathrm{c}_{k}\right), \mathrm{k}=1,2, \ldots, \mathrm{K}$, then compute aggregate fuzzy ratings as $\tilde{R}=(\mathrm{a}, \mathrm{b}, \mathrm{c})$, where 
$a=\min _{k}\left\{\mathrm{a}_{k}\right\}, \quad b=\frac{1}{K} \sum_{k=1}^{k} b_{k}, \quad c=\max _{k}\left\{\mathrm{c}_{k}\right\}$.

If the kth expert ratings is $\tilde{x}_{i j k}=\left(\mathrm{a}_{i j k}, \mathrm{~b}_{i j k}, \mathrm{c}_{i j k}\right)_{\mathrm{i}=} 1,2, \ldots, m, j=1,2, \ldots, \mathrm{n}$, then aggregate fuzzy ratings of candidate project is $\tilde{x}_{i j}=\left(\mathrm{a}_{i j}, \mathrm{~b}_{i j}, \mathrm{c}_{i j}\right)$, where

$a_{i j}=\min _{k}\left\{\mathrm{a}_{i j k}\right\} \quad b_{i j}=\frac{1}{K} \sum_{k=1}^{K} b_{i j k}, \quad c_{i j}=\max _{k}\left\{\mathrm{c}_{i j k}\right\}$

Step 3 Compute candidate projects A's fuzzy decision matrix $(\tilde{D})$ as below:

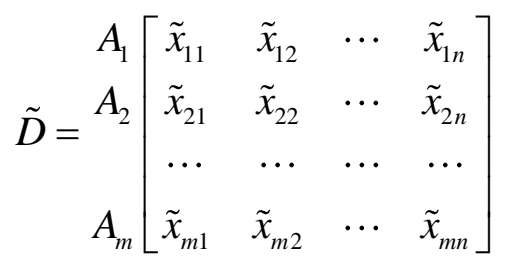

Step 4 Normalize fuzzy decision matrix:

Through linear conversion to eliminate the impact of indicators dimension, which is denoted by $\tilde{R}$, whose elements are $\left[\tilde{\mathrm{r}}_{i j}\right]_{m \times n} i=1,2, \ldots, \mathrm{m} ; \mathrm{j}=1,2, \ldots, n$.

$\tilde{R}=\left[\tilde{\mathrm{r}}_{i j}\right]_{m \times n}, i=1,2, \ldots, \mathrm{m} ; \mathrm{j}=1,2, \ldots, n$

among, $\quad \tilde{\mathrm{r}}_{i j}=\left(\frac{a_{i j}}{c_{j}^{*}}, \frac{b_{i j}}{c_{j}^{*}}, \frac{c_{i j}}{c_{j}^{*}}\right)$, also $c_{j}^{*} \max _{i} c_{i j}$ (beneficial criteria)

$\tilde{\mathrm{r}}_{i j}=\left(\frac{a_{j}^{-}}{a_{i j}}, \frac{a_{j}^{-}}{b_{i j}}, \frac{a_{j}^{-}}{c_{i j}}\right)$, also $a_{j}^{-}=\min _{i} a_{i j}$ (costly criteria)

Step 5 Compute fuzzy positive ideal solution (FPIS) and fuzzy negative ideal solution (FPIS):

$$
\begin{aligned}
& A^{*}=\left(\tilde{v}_{1}^{*}, \tilde{v}_{2}^{*}, \ldots, \tilde{v}_{n}^{*}\right), \text { meanwhile, } \quad \tilde{v}_{j}^{*}=\left(\tilde{\mathrm{c}}_{j}^{*}, \tilde{\mathrm{c}}_{j}^{*}, \tilde{\mathrm{c}}_{j}^{*}\right) \text { and } \tilde{\mathrm{c}}_{j}^{*}=\max _{i}\left\{\tilde{\mathrm{c}}_{i j}\right\} \\
& A^{-}=\left(\tilde{v}_{1}^{-}, \tilde{v}_{2}^{-}, \ldots, \tilde{v}_{n}^{-}\right), \text {meanwhile, } \tilde{v}_{j}^{-}=\left(\tilde{\mathrm{a}}_{j}^{-}, \tilde{\mathrm{a}}_{j}^{-}, \tilde{\mathrm{a}}_{j}^{-}\right) \text {and } \tilde{a}_{j}^{-}=\max _{i}\left\{\tilde{\mathrm{a}}_{i j}\right\} \\
& \mathrm{i}=1,2, \ldots, m, j=1,2, \ldots, \mathrm{n} \text { 。 }
\end{aligned}
$$

Step 6 The distance from FPIS $\left(\mathrm{d}_{i}^{+}\right)$and gap from FNIS $\left(\mathrm{d}_{i}^{-}\right)$are denoted by

$$
\begin{aligned}
\mathrm{d}_{i}^{+} & =\sum_{j=1}^{n} d_{v}\left(\tilde{v}_{i j}, \tilde{v}_{j}^{*}\right), \mathrm{i}=1,2, \ldots, \mathrm{m} . \\
\mathrm{d}_{i}^{-} & =\sum_{j=1}^{n} d_{v}\left(\tilde{v}_{i j}, \tilde{v}_{j}^{-}\right), \mathrm{i}=1,2, \ldots, \mathrm{m} .
\end{aligned}
$$

where 


$$
d_{v}(\tilde{a}, \tilde{\mathrm{b}})=\sqrt{\frac{1}{3}} \sqrt{\left[\left(\mathrm{a}_{1}-b_{1}\right)^{2}+\left(\mathrm{a}_{2}-b_{2}\right)^{2}+\left(\mathrm{a}_{3}-b_{3}\right)^{2}\right]}
$$

Step 7 The respective closeness to the ideal value is determined and projects are sorted accordingly, which is given by $C C_{i}$

$$
C C_{i}=\frac{d_{i}^{-}}{d_{i}^{-}+d_{i}^{+}}, \mathrm{i}=1,2, \ldots, \mathrm{m} .
$$

\section{Case Study}

The case study involves the sorting of informatization project based on risk evaluation using Fuzzy-TOPSIS evaluation model, including three steps:

I. Apply AHP to distribution criteria weight.

II. Using Fuzzy-TOPSIS to sort informatization project based on risk evaluation.

III. Apply sensitivity analysis (SA) [13] to decide the influence of criteria weight change to risk level of informatization project.

\subsection{Criteria System of Informatization Project}

Ocean engineering enterprises assess and manage informatization project factors facing informatization construction, in order to control risk efficiently. Informatization project needs to integrate technology, organization, personnel, funds in total of four modules to realize the integration. This is also serves as owners measuring the level of project management [9], integrate informatization project frame of technology and organization and the information system success factors, according to the characters of ocean engineering enterprise informatization projects [10], constructing technology informatization risk, organization informatization risk, personnel informatization risk, funds informatization risk in total of four layers of informatization project risk criteria system. The details of indicators like Table 2 . 
Table 2. Ocean Enterprise Evaluation Indicators of Informatization Projects

\begin{tabular}{|c|c|c|c|c|}
\hline ID & $\begin{array}{l}\text { First grade } \\
\text { criteria }\end{array}$ & $\begin{array}{l}\text { Second grade } \\
\text { Criteria }\end{array}$ & Criteria explanations & Type \\
\hline $\mathrm{C} 1$ & $\begin{array}{l}\text { Technology } \\
\text { risk }\end{array}$ & Batch plot level & $\begin{array}{l}\text { The main hull, structure, outfitting conceptual } \\
\text { model design }\end{array}$ & $B(\uparrow)$ \\
\hline $\mathrm{C} 2$ & $\begin{array}{l}\text { Technology } \\
\text { risk }\end{array}$ & $\begin{array}{l}\text { (Tribon 3D } \\
\text { Modeling) }\end{array}$ & $\begin{array}{l}\text { Synchronization with production management, } \\
\text { assist overall design to reduce design errors and } \\
\text { shorten the construction period }\end{array}$ & $B(\uparrow)$ \\
\hline $\mathrm{C} 3$ & $\begin{array}{l}\text { Technology } \\
\text { risk }\end{array}$ & $\begin{array}{l}\text { Leg, cantilever } \\
\text { beam quality } \\
\text { control }\end{array}$ & $\begin{array}{l}\text { The quality sector carry on the strict control of } \\
\text { weight and precision of key projects of platform } \\
\text { building ,such as cantilever beam, the legs etc. }\end{array}$ & $B(\uparrow)$ \\
\hline $\mathrm{C} 4$ & $\begin{array}{l}\text { Technology } \\
\text { risk }\end{array}$ & $\begin{array}{l}\text { Cantilever } \\
\text { beam, rig } \\
\text { welding quality }\end{array}$ & $\begin{array}{l}\text { The quality sector carry on one-time crack } \\
\text { inspection, the inspection checks for cantilever } \\
\text { beam, the legs }\end{array}$ & $B(\uparrow)$ \\
\hline C5 & $\begin{array}{l}\text { Technology } \\
\text { risk }\end{array}$ & $\begin{array}{l}\text { Dynamic } \\
\text { positioning } \\
\text { system }\end{array}$ & $\begin{array}{l}\text { A closed-loop control system, adopting the } \\
\text { thruster to provide resistance to wind, wave and } \\
\text { flow forces of ship's external environment, and } \\
\text { keep heading and position of "still" }\end{array}$ & $B(\uparrow)$ \\
\hline C6 & $\begin{array}{l}\text { Organizational } \\
\text { risk }\end{array}$ & $\begin{array}{l}\text { hull section } \\
\text { drawing }\end{array}$ & $\begin{array}{l}\text { According to the ship's quantity, the seam } \\
\text { position and theoretical quality and every block } \\
\text { fitting allowance and the number of parts }\end{array}$ & $B(\uparrow)$ \\
\hline $\mathrm{C} 7$ & $\begin{array}{l}\text { Organizational } \\
\text { risk }\end{array}$ & $\begin{array}{l}\text { The key } \\
\text { equipment } \\
\text { procurement }\end{array}$ & $\begin{array}{l}\text { delayed procurement of key equipment will lead } \\
\text { to delay overall project schedule, therefore, to } \\
\text { ensure that key equipment purchasing ability }\end{array}$ & $B(\uparrow)$ \\
\hline $\mathrm{C} 8$ & $\begin{array}{l}\text { Organizational } \\
\text { risk }\end{array}$ & $\begin{array}{l}\text { Venue, crane } \\
\text { resources } \\
\text { coordination }\end{array}$ & $\begin{array}{l}\text { Platform, spud leg, lifter and other important } \\
\text { equipment for hoisting in place, therefore, } \\
\text { coordinate space and crane resources to ensure } \\
\text { construction platform smoothly }\end{array}$ & $B(\uparrow)$ \\
\hline C9 & $\begin{array}{l}\text { Organizational } \\
\text { risk }\end{array}$ & $\begin{array}{l}\text { Debugging } \\
\text { quality level }\end{array}$ & $\begin{array}{l}\text { Adjust related equipment of the system } \\
\text { engineering, calibration and experiment, and } \\
\text { make it meet the application requirement of } \\
\text { drilling platform as a whole }\end{array}$ & $B(\uparrow)$ \\
\hline $\mathrm{C} 10$ & Funding risk & $\begin{array}{l}\text { Automated } \\
\text { processing of } \\
\text { capital } \\
\text { transaction }\end{array}$ & $\begin{array}{l}\text { Provide financial accounting, analysis, trading, } \\
\text { control during Internet environment enhance the } \\
\text { level of the trading efficiency of funds and trade } \\
\text { integration, integrated management and improve } \\
\text { financial management level and economic } \\
\text { benefits }\end{array}$ & $B(\uparrow)$ \\
\hline C11 & Funding risk & $\begin{array}{l}\text { Capital Real- } \\
\text { time } \\
\text { synchronization }\end{array}$ & $\begin{array}{l}\text { Based on accounting information, fully } \\
\text { implementing the network finance, } \\
\text { implementation flow of synchronization }\end{array}$ & $B(\uparrow)$ \\
\hline $\mathrm{C} 12$ & $\begin{array}{l}\text { Organizational } \\
\text { risk }\end{array}$ & $\begin{array}{l}\text { Block assembly } \\
\text { risk }\end{array}$ & $\begin{array}{l}\text { In order to adapt to shipbuilding need hull } \\
\text { section and the benchmark hull totally } \\
\text { assembling with welding process risk }\end{array}$ & $B(\downarrow)$ \\
\hline $\mathrm{C} 13$ & Personnel risk & $\begin{array}{l}\text { HSE safety } \\
\text { check risk }\end{array}$ & $\begin{array}{l}\text { Marine companies generally follow the health, } \\
\text { safety, environment inspection risk }\end{array}$ & $B(\downarrow)$ \\
\hline $\mathrm{C} 14$ & Personnel risk & $\begin{array}{l}\text { Workshop } \\
\text { coordination } \\
\text { risk }\end{array}$ & $\begin{array}{l}\text { Subordinate four workshops (every block of } \\
\text { coordination with steel material processing, } \\
\text { manufacture, coating and fitting out) }\end{array}$ & $B(\downarrow)$ \\
\hline $\mathrm{C} 15$ & Personnel risk & $\begin{array}{l}\text { Arrival } \\
\text { equipment } \\
\text { inspection risk }\end{array}$ & $\begin{array}{l}\text { debugging department cooperate with quality } \\
\text { department, the project team and other } \\
\text { departments involved in inspection work of }\end{array}$ & $B(\downarrow)$ \\
\hline
\end{tabular}




$\begin{array}{llll}\text { C16 Personnel risk } & \begin{array}{l}\text { risk of } \\ \text { mechanical } \\ \text { completion } \\ \text { confirmation }\end{array} & \begin{array}{l}\text { arrival equipment } \\ \text { Debugging department complete the mechanical } \\ \text { completion confirmation, check, perfect } \\ \text { document management work in the platform } \\ \text { construction }\end{array}\end{array}$

Notes: there are two types of criteria, $B(\uparrow)$ the higher the better; $B(\downarrow)$ represents oppositely.

\subsection{Criteria Weight using AHP}

Linguistic terms are subjective discriminant for the linguistic variables. A linguistic variable whose values are words or sentences in a natural or artificial language. Here, we use this kind of expression to compare two criteria dimensions using nine basic linguistic terms, as "Perfect", "Absolute", "Very good" ,"Fairly good" "Good","Perferable","Not bad", "Weak advantage", "Equal" respect to a fuzzy number.

Evaluation commission consisting of the owner (D1), suppliers (D2), Technical Director (D3), Project Manager (D4), Purchasing Manager (D5) in total of five stakeholders sort informatization project risk level of XX drilling platform. Sorting of ocean engineering enterprise contains 16 indicators of 4 informatization projects (A1, A2, A3, A4), criteria weights calculated by AHP are shown in Table 3, where the consistency ratio( CR) follows: Evaluation goals, 0.0556; Technical risk, 0.0754;Organization risk, 0.0444; Personnel risk, 0.0608; Funds risk, 0,are all to meet the requirements of consistency ratio $\mathrm{CR}<0.01$.

Table 3. Criteria Weight

\begin{tabular}{|c|c|c|}
\hline Indicators & Secondary & $\begin{array}{l}\text { Overall } \\
\text { weight }\end{array}$ \\
\hline \multirow{5}{*}{$\begin{array}{l}\text { Technical risk ( } \\
0.1341)\end{array}$} & Batch plot level（0.3406） & 0.0457 \\
\hline & Optimized design level $(0.4125)$ & 0.0553 \\
\hline & Leg, cantilever quality control standards $(0.1224)$ & 0.0016 \\
\hline & $\begin{array}{l}\text { Completeness of information security standards ( } \\
0.0774)\end{array}$ & 0.0104 \\
\hline & Rig, welding quality control standards $(0.0470)$ & 0.0063 \\
\hline \multirow{5}{*}{$\begin{array}{l}\text { Organization risk（ } \\
0.0615 ）\end{array}$} & Hull segmented plot level（0.2633） & 0.0162 \\
\hline & The key equipment procurement level (0.5579) & 0.0343 \\
\hline & Site, cranes resource coordination $(0.1219)$ & 0.0075 \\
\hline & Fold risk segmentation $(0.0687)$ & 0.0190 \\
\hline & Quality level debugging (0.0569) & 0.0035 \\
\hline Personnel risk & HSE risk security check（0.2623） & 0.0724 \\
\hline \multirow[t]{3}{*}{$0.2761)$} & Workshop coordination of risk $(0.4966)$ & 0.1371 \\
\hline & Test equipment arrival risk $(0.1358)$ & 0.0375 \\
\hline & $\begin{array}{l}\text { Mechanical Completion confirmation risk }(0.0366 \\
\text { ) }\end{array}$ & 0.0101 \\
\hline \multirow[t]{2}{*}{$\begin{array}{l}\text { Funds risk }(0.5283 \\
\text { ) }\end{array}$} & $\begin{array}{l}\text { Automated processing of financial transactions }(0.5 \\
\text { ) }\end{array}$ & 0.2641 \\
\hline & Real-time synchronization of funds $(0.5)$ & 0.2641 \\
\hline
\end{tabular}




\subsection{Project Evaluation and Sort using fuzzy-TOPSIS}

The four projects evaluation of linguistic scale there are five decision-makers, who are Ship owner, Supplier, Technical Director, Project Manager and Purchasing Manager, Using equation (2) to calculate the total fuzzy weights of alternative project. For example, to criteria $\mathrm{C} 1$ of proposal $\mathrm{A} 1$, the overall evaluation matrix presented in Table 4.Its evaluation process of five experts and calculation as the following:

$$
\mathrm{a}_{i j}=\min _{k}(7,5,5,3,5), \mathrm{b}_{i j}=\frac{1}{5} \sum_{k=1}^{5}(9+7+7+5+7), \mathrm{c}_{i j}=\max _{k}(9,9,9,7,9)
$$

Table 4. Fuzzy Evaluation Matrix

\begin{tabular}{clllll}
\hline Criteria & \multicolumn{1}{c}{$\mathrm{A} 1$} & \multicolumn{1}{c}{$\mathrm{A} 2$} & $\mathrm{~A} 3$ & $\mathrm{~A} 4$ \\
\hline $\mathrm{C} 1$ & $(5,6.4,9)$ & $(3,4.8,9)$ & $(3,5.2,9)$ & $(3,5.2,9)$ \\
$\mathrm{C} 2$ & $(1,3.6,7)$ & $(3,4.8,9)$ & $(1,4,9)$ & $(1,4.4,9)$ \\
$\mathrm{C} 3$ & $(3,5.2,9)$ & $(3,4.8,9)$ & $(3,4.8,9)$ & $(3,4.8,9)$ \\
$\mathrm{C} 4$ & $(1,4.4,9)$ & $(1,3.6,9)$ & $(3,4.8,9)$ & $(3,5.6,9)$ \\
$\mathrm{C} 5$ & $(5,6,9)$ & $(3,6,9)$ & $(3,6,9)$ & $(5,6.4,9)$ \\
$\mathrm{C} 6$ & $(5,6.8,9)$ & $(3,5.6,9)$ & $(5,6.8,9)$ & $(3,5.2,9)$ \\
$\mathrm{C} 7$ & $(3,5.6,9)$ & $(1,4,9)$ & $(1,4.4,9)$ & $(1,4,9)$ \\
$\mathrm{C} 8$ & $(5,6.8,9)$ & $(5,6,9)$ & $(5,6.4,9)$ & $(3,5.2,9)$ \\
$\mathrm{C} 9$ & $(1,5.2,9)$ & $(3,4.4,9)$ & $(3,4.8,9)$ & $(5,6.4,9)$ \\
$\mathrm{C} 10$ & $(5,6,9)$ & $(5,6.4,9)$ & $(3,5.6,9)$ & $(3,5.2,9)$ \\
$\mathrm{C} 11$ & $(3,5.6,9)$ & $(3,5.6,9)$ & $(3,5.2,9)$ & $(3,5.2,9)$ \\
$\mathrm{C} 12$ & $(3,4.8,9)$ & $(3,5.2,9)$ & $(3,5.2,9)$ & $(3,5.2,9)$ \\
$\mathrm{C} 13$ & $(3,5.2,9)$ & $(1,4.4,9)$ & $(1,3.6,7)$ & $(5,5.6,9)$ \\
$\mathrm{C} 14$ & $(1,3.2,9)$ & $(1,3.6,9)$ & $(1,3.2,7)$ & $(1,4,9)$ \\
$\mathrm{C} 15$ & $(5,6.4,9)$ & $(3,4.8,9)$ & $(3,5.2,9)$ & $(5,6,9)$ \\
$\mathrm{C} 16$ & $(5,5.6,9)$ & $(3,5.2,9)$ & $(5,6,9)$ & $(3,5.6,9)$ \\
\hline
\end{tabular}

After obtaining all the fuzzy scores, using equation (5), (6) to standardize the fuzzy evaluation matrix, and then, applying the formula (3) to get fuzzy weights matrix for four projects. While, using the formula (7) and (8) to calculate the fuzzy positive ideal solution $\left(A^{*}\right)$ and fuzzy negative ideal solution to $\left(A^{-}\right)$. Afterwards, apply formula (9), (10) to calculate the distance $\mathrm{d}_{i}^{+}$of each project to $A^{*}$ and $d_{i}^{-}$of each project to $A^{-}$.Finally using formula (12) to calculate the relative closeness coefficient $C C_{i}$ of four informatization projects. For example A1, relatively closeness coefficient as follows:

$$
C C_{i}=\frac{d_{i}^{-}}{d_{i}^{-}+d_{i}^{+}}=0.4163 /(0.4163+0.3953)=0.5129
$$

Assemble expert evaluation matrix ,obtaining a comprehensive attribute values shown in Table 5, it gives the results of Fuzzy-TOPSIS evaluation, and normalizing the evaluation results, we find that the, according the score, the sorting of the alternatives is $A 1 \succ A 3 \succ A 4 \succ A 2$. 
Table 5. Informatization Projects Comprehensive Attributes of Ocean Engineering Enterprise

\begin{tabular}{ccccc}
\hline Method & A1 & A2 & A3 & A4 \\
\hline Fuzzy-TOPSIS & 0.5129 & 0.4557 & 0.4986 & 0.4972 \\
Normalized & 0.2611 & 0.2320 & 0.2538 & 0.2531 \\
\hline
\end{tabular}

\subsection{Sensitivity Analysis of Informatization Project Risk}

In order to investigate the impact of indicators weights to the level of risk for informatization projects, we use sensitivity analysis to illustrate, Table 6 shows the experimental details.

Table 6. Sensitivity Analysis Experiment

\begin{tabular}{|c|c|c|c|c|c|}
\hline \multirow{2}{*}{ Exp. } & \multirow{2}{*}{ Definition } & \multicolumn{4}{|c|}{ Scores } \\
\hline & & A1 & $\mathrm{A} 2$ & A3 & A4 \\
\hline 1 & $\omega_{C 1}=0.625, \omega_{C 2-C 16}=0.025$ & 0.5276 & 0.4468 & 0.4651 & 0.4614 \\
\hline 2 & $\omega_{C 3}=0.625, \omega_{C 1-C 2, C 4-C 16}=0.025$ & 0.4347 & 0.4271 & 0.4534 & 0.4445 \\
\hline 3 & $\omega_{C 3}=0.625, \omega_{C 1-C 2, C 4-C 16}=0.025$ & 0.4502 & 0.4468 & 0.4578 & 0.4541 \\
\hline 4 & $\omega_{C 4}=0.625, \omega_{C 1-C 3, C 5-C 16}=0.025$ & 0.4613 & 0.4521 & 0.5085 & 0.5204 \\
\hline 5 & $\omega_{C 5}=0.625, \omega_{C 1-C 4, C 6-C 16}=0.025$ & 0.3366 & 0.4416 & 0.4525 & 0.3360 \\
\hline 6 & $\omega_{C 6}=0.625, \omega_{C 1-C 5, C 7-C 16}=0.025$ & 0.5371 & 0.4616 & 0.5438 & 0.4614 \\
\hline 7 & $\omega_{C 7}=0.625, \omega_{C 1-C 6, C 8-C 16}=0.025$ & 0.5256 & 0.4583 & 0.4739 & 0.4644 \\
\hline 8 & $\omega_{C 8}=0.625, \omega_{C 1-C 7, C 9-C 16}=0.025$ & 0.3240 & 0.3348 & 0.3470 & 0.4612 \\
\hline 9 & $\omega_{C 9}=0.625, \omega_{C 1-C 8, C 10-C 16}=0.025$ & 0.4291 & 0.2657 & 0.2762 & 0.4364 \\
\hline 10 & $\omega_{C 10}=0.625, \omega_{C 1-C 9, C 11-C 16}=0.025$ & 0.3366 & 0.3280 & 0.4650 & 0.4612 \\
\hline 11 & $\omega_{C 11}=0.625, \omega_{C 1-C 10, C 12-C 16}=0.025$ & 0.4506 & 0.4472 & 0.4731 & 0.4612 \\
\hline 12 & $\omega_{C 12}=0.625, \omega_{C 1-C 11, C 13-C 16}=0.025$ & 0.4658 & 0.4539 & 0.4650 & 0.4612 \\
\hline 13 & $\omega_{C 13}=0.625, \omega_{C 1-C 12, C 14-C 16}=0.025$ & 0.2602 & 0.4304 & 0.4490 & 0.2245 \\
\hline 14 & $\omega_{C 14}=0.625, \omega_{C 1-C 13, C 15-C 16}=0.025$ & 0.4434 & 0.4363 & 0.4535 & 0.4390 \\
\hline 15 & $\omega_{C 15}=0.625, \omega_{C 1-C 14, C 16}=0.025$ & 0.5180 & 0.4468 & 0.4651 & 0.5210 \\
\hline 16 & $\omega_{C 16}=0.625, \omega_{C 1-C 15}=0.025$ & 0.4576 & 0.4399 & 0.4804 & 0.4614 \\
\hline 17 & $\omega_{C 1-C 16}=0.0625$ & 0.4347 & 0.4271 & 0.4534 & 0.4445 \\
\hline
\end{tabular}




$$
\omega_{C 1-C 8}=0.1250, \omega_{C 9-C 16}=0
$$

$$
\omega_{C 1-C 8}=0, \omega_{C 9-C 16}=0.1250
$$

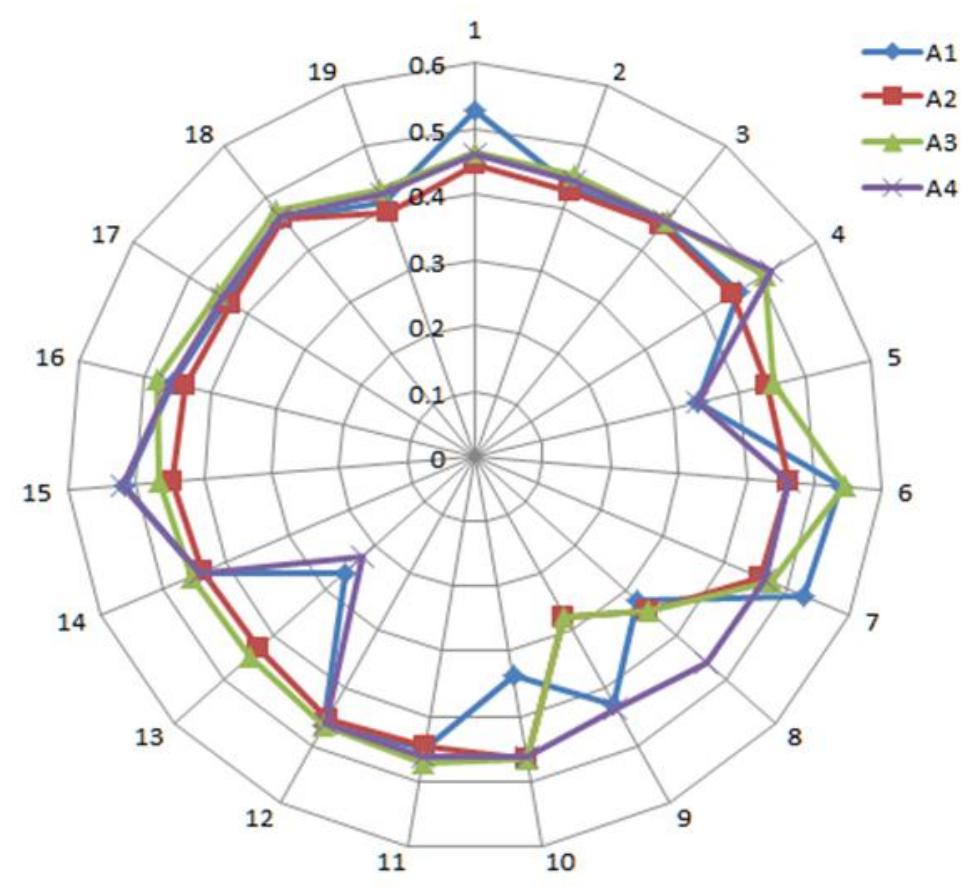

Figure 2. Results of Sensitivity Analysis $\left(C C_{i}\right)$

As can be seen from the 19 results of Table 6, each criteria of each experiment is set to the maximum weight in turn, correspondingly, other indicators are set the minimum and equal weights. For example, in Exp1, indicator $\mathrm{C} 1$ has the weight of 0.625 and the remainings $(\mathrm{C} 2-\mathrm{C} 15)$ weights are assumed to be the same weight, for which they are assigned equal weights 0.025 , meeting $1-0.625=0.025 * 15$. Therefore, in Exp1 to 15, we also guarantee a maximum criteria weight of 0.625 , and the remaining indicators are equally weight 0.025 . In the Exp17, we have designed a comparison proposal, all the indicators weights are set equal values, namely $0.0625=1 / 16$; Exp 18 means the former eight benefical indicators $(\mathrm{C} 1 \sim \mathrm{C} 8)$ set an average weight, the remaining costly criteria $(\mathrm{C} 9 \sim \mathrm{C} 16)$ weights are 0 , to reflect impact on risk level of informatization projects for benefical indicators weight; Exp 19 has opposite meaning, weights of costly indicators are zero, while the other eight benefical indicators are with equal weights of $0.125=1 / 8$; However, for experiment indicators weights having slight changes in the error, you can set up more experiments according to relevant research questions.

\section{Results and Discussions}

From Fuzzy-TOPSIS evaluation results, the risk level of the four informatization projects from low to high is $\mathrm{A} 1 \succ \mathrm{A} 3 \succ \mathrm{A} 4 \succ \mathrm{A} 2$, the greater the $\mathrm{CCi}$, the lower is the project risk, the closer to the ideal decision target. 
As can be seen from Table 6 and Figure 2, from little changes $[-\partial, \partial]$ of weight range in Exp 19, considering weight changes to $\omega+-\partial$, we can prove that the 19 experiments are the most effective to our study, project A3 has the highest score in 11/19 experiments, therefore, we can say risk level for informatizaiton projects to A3 is the most sensitive, for example, Exp 5 and 9 has exactly opposite effect on the risk, indicating the level of key equipment procurement makes the risk level of informatization projects for A2 and A3 significantly decreasing, while greatly increasing the risk level of A1 and A4,in Exp 5 , the project A2 compared to attributes with equal weights (test 17) reduced $12.48 \%$ of risk level; while influenced by equipment procurement, risk level of A1 improved $29.14 \%$.At the same time, if adjust risk weights of technology, organization, personnel, funds indicators of informatization projects, the final result will be changed.

\section{Conclusion}

On the basis of informatization project risk research, introducing triangular fuzzy number to TOPSIS, complete sorting of four ocean enterprise informatization projects based on risk assessment, then through sensitivity analysis experiments to evaluate the impact of weight change on project sorting. Through the research, we can get the following conclusions.

First, combine multi-attribute evaluation model creatively, simultaneous, apply to the risk sorting of ocean enterprise informatization projects, meanwhile, providing a new perspective and range of applications for the project chosen.

Second, more reasonable and scientific than traditional program evaluation model. Application of mature evaluation method of Fuzzy-TOPSIS based on risk assessment of marine enterprise informatization projects with empirical research.

Advantages of Fuzzy-TOPSIS is in its practical application and limited conditions of information with making reliable evaluation. Inadequacy lies in the number of involved experts and their understanding of informatization project risks within a limited extent. Therefore, the whole project implementation process of enterprise informatization need mine more typical and key risks, and meanwhile confirming the validity of the risk assessment for marine project model by comparing existing comprehensive evaluation method.

\section{References}

[1] W. D. Jie, "Risk causes and countermeasures of H CO.as informatization construction", Huazhong agricultural university, Wuhan, (2013).

[2] M. W. Hua, "Risk management of marine electrical equipment", China Water Transport, vol. 7, (2007), pp. 68-69.

[3] G. D. Qiang, "Application of entropy weight coefficient method to the evaluation of enterprise informatization", Operations research and management science, vol. 3, (2003), pp. 77-80.

[4] H. J. Xun and R. Wei, "Study on the risk information management method of ship construction", Science \& Technology Vision, vol. 9, (2013), pp. 51-52.

[5] K. T. Yeo, "Critical failure factors in information system projects", International Journal of Project Management, vol. 3, no. 20, (2002), pp. 241-246.

[6] S. Pettera and W. DeLoneb, E. R. McLeanc, "Information Systems Success: The Quest for the Independent Variables", Management Information Systems, vol. 4, no. 29, (2013), pp. 7-62.

[7] A. Mateos and A. Jimènez, S. Ríos-Insua, "Monte Carlo simulation techniques for group decision making with incomplete information", Eur J Oper Res, vol. 174, no. 3, (2006), pp. 1842-1864.

[8] R. Vetschera and P. Sarabando, L. Dias, "Levels of incomplete information in group decision models A comprehensive situation study", Computers \& Operations Research, vol. 5, (2014), pp. 160-171.

[9] The ministry and information technology, Guide the scientific research project of marine engineering equipment. Ministry and information technology, Beijing (2014).

[10] Y. Y. Xiang. Chuan Bo Yu Hai Yang Ping Tai Jie Gou, "National Defense Industry Press", Beijing, (2012).

[11] W. Pedrycz, “Why triangular membership function?”, Fuzzy Sets Syst, vol. 64, (1994), pp. 21-30. 
[12] G. R. Klir and B. Yuan, "Fuzzy Sets and Fuzzy Logic Theory and Appilication", Upper Saddle River, NJ, (1995).

[13] A. Awasthi and S. S. Chauhan, "A hybrid approach integrating Affinity Diagram”, AHP and fuzzy TOPSIS for sustainable city logistics planning, Applied Mathematical Modelling, vol. 36, (2012), pp. 573-584.

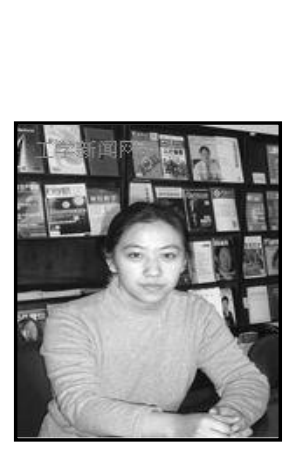

\begin{abstract}
Authors
Yan Song, She received the B.Sc. and M.S. degree in the college of Computer Science and Technology in 1995 and 1999, respectively, and the Ph.D. degree in Management Science and Engineering from the Harbin Engineering University, Harbin, China, in 2004.

From 2004 to 2008, she was Postdoctoral at School of Management, Harbin Institute of Technology, during 2005 to 2006, she was academic visitor at School of Economics, Tilburg University, Holland. She is the editorial board member of ISCRAM Journal. She also is the founder of international conference of ISCRAM-CHINA and the chairman of Academic committee. She current is interested in risk estimation and risk management and their applications.
\end{abstract}

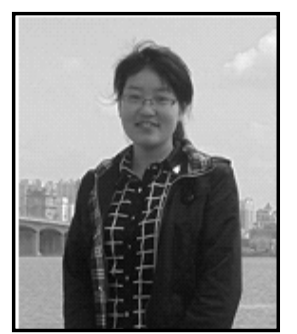

Shuang Yao, She received the B.Sc. degree in Information Management and System from the College of Computer Science and Technology in Northeast Forestry University, Harbin, China, in 2012.

She is currently a successive postgraduate and doctoral candidate in School of Economics and Management, Harbin Engineering University, Harbin, China. Her current research interests is Informatization, Risk management, Industrial agglomeration and their related applications. 